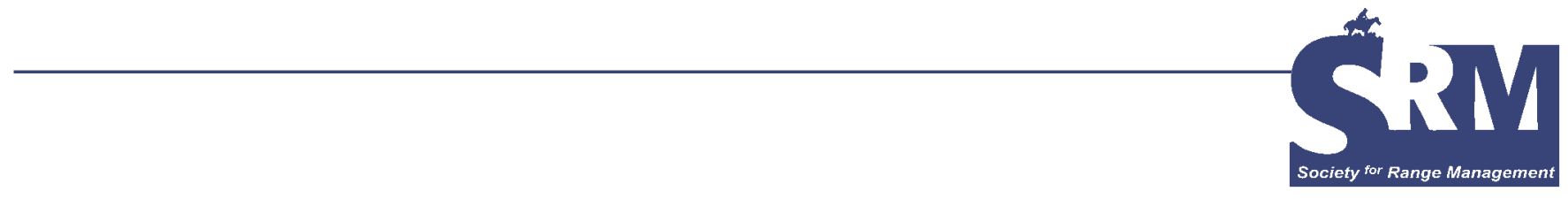

\title{
SRM Honor Awards
}

\section{Presented at the Society's 59th Annual Meeting in Vancouver, British Columbia, on February 15, 2006.}

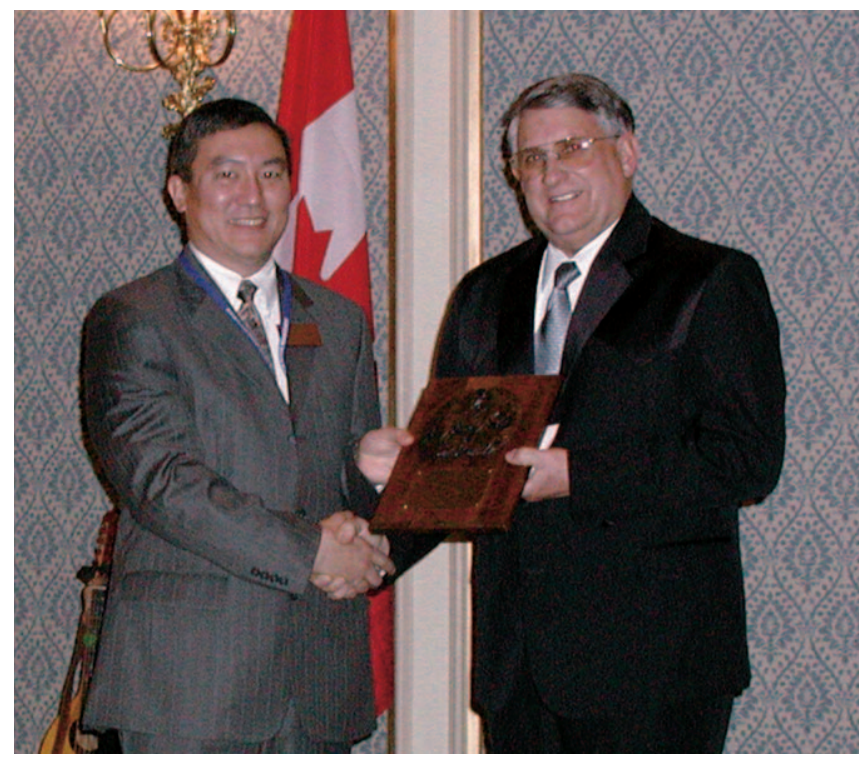

John Tanaka and Gary Frasier

The Fredric G. Renner Award is the highest bestowed by the Society for Range Management. The award is named for one of the SRM's founding fathers, who served as its 2 nd President.

The Society for Range Management's most prestigious award, the Fredrick G. Renner Award, is presented this year to Gary W. Frasier.

Gary qualifies for this recognition because of the outstanding contributions he has made to the Society through his 20-plus years of service as editor of Rangelands and the Journal of Range Management and because of the many con- tributions he has made in his 42 years of rangeland research as a scientist working for the Agricultural Research Service (ARS). Much of this work was conducted on rangelands of Arizona and Colorado.

Because of his editorial work, Rangelands and the Journal of Range Management-now known as Rangeland Ecology \& Management-have become very informative and highly respected publications. The quality of the articles in both publications improved under Gary's leadership, as did the presentation quality of the materials in these articles. Gary has sought out authors from inside and outside the Society to write synthesis articles that have become benchmarks of our profession. Because these publications are the most visible aspect of the Society, Gary has-as much or more than any other individual-ensured that $\mathrm{SRM}$ is recognized as a valuable and respected professional organization. Gary has not limited his editorial contributions to SRM publications; he has also served on the editorial board for the Journal of Plant Interactions (Taylor \& Francis, UK, publisher).

Gary's research career with ARS encompassed 3 major areas: 1) water supply (water harvesting), 2) rangeland revegetation (water requirements for plant establishment), and 3) rangeland surface water hydrology (runoff and infiltration). Gary's research represents a body of quality work. He has authored or coauthored over 120 technical publications-67 as senior or sole author, including over 20 in the Journal of Range Management. Several of his publications are considered to establish the state-of-the-art for rangeland hydrology and water supplies on arid rangelands. Gary is also very 
well respected for his willingness and ability to engage in interdisciplinary research efforts with other scientists.

In addition to his work with ARS, Gary has been an affiliated faculty member of the Forest, Rangeland, and Watershed Stewardship Department at Colorado State University. His interdisciplinary approach has made him a particularly valuable advisor of graduate students. He has served as research advisor or coadvisor for $10 \mathrm{MS}$ and $4 \mathrm{PhD}$ students and project leader for 2 US Department of Agriculture (USDA)-funded research projects to investigate the impacts of cattle grazing on infiltration, runoff, and erosion in riparian ecosystems. He is currently coproject leader in a joint ARS and Colorado State University (CSU) longterm study to determine the impact of soil loss on vegetative, hydrologic, and soil resources and the long-term sustainability of shortgrass steppe and cold desert sagebrush ecosystems.

For his lifetime of commitment to the Society and to rangelands, the Society for Range Management is proud to present Gary W. Frasier with the Frederic G. Renner Award.

The W. R. Chapline Research Award was established in 1986 to provide recognition to members of SRM for exceptional research accomplishments in range science and related disciplines.

Dr Gerald (Jerry) E. Schuman is recognized as the leading international authority on mined-land reclamation and carbon sequestration in rangelands. His research contributions in assessing soil responses to land management practices in semiarid and arid rangeland ecosystems, which have addressed customer-relevant problems, are unparalleled.

Jerry's professional contributions to the field of range management include mentoring 34 graduate students, publishing more than 175 scientific articles, and accepting numerous leadership positions.

He has continually provided high-quality, practical research for the land manager, addressing contemporary issues while concurrently advancing the state of knowledge in soil carbon and nitrogen cycling. Jerry's research addressed key customer issues at regional, national, and international levels and has had significant impact on public policy. This focus on customer issues is quite evident because the majority of his research has been productive and cooperative projects with the private sector (eg, coal mining companies, individual land owners), so that his research is often used for demonstration purposes by organizations and local, state, regional, and national agencies.

Jerry's research into land rehabilitation has led to the development and acceptance of technology that is used by the mining industry throughout the United States and in many other countries.

Jerry's cutting-edge research on the development of soil quality and rangeland health parameters and indicators and on the evaluation of land management practices that enhance carbon sequestration in rangeland ecosystems represents a major breakthrough in the transfer of technology to

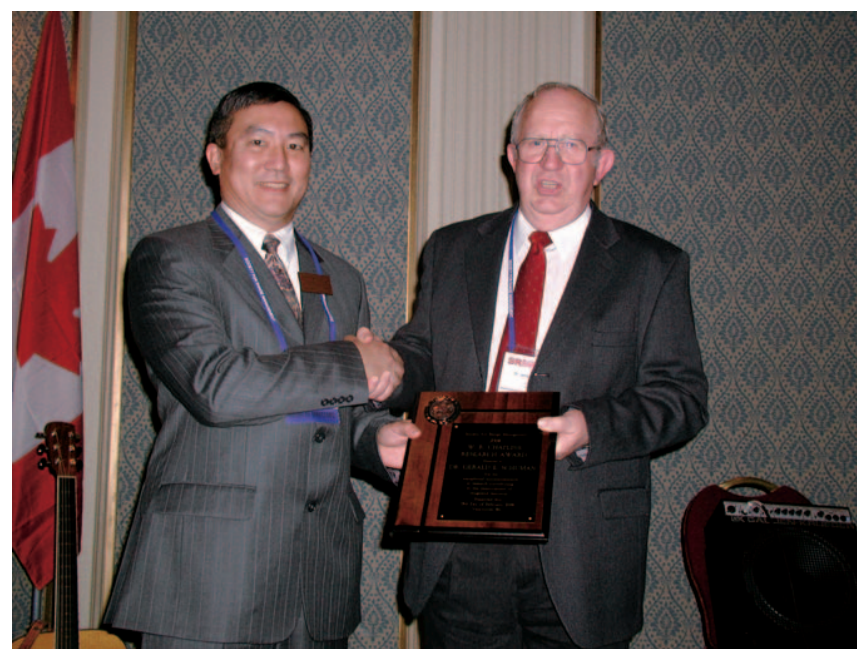

John Tanaka and Gerald Schuman

land management and natural resource agencies. Because this area of research is recognized as experimentally difficult and complex and does not readily submit to conventional approaches in research analysis, Jerry's contributions to improving the understanding of rangeland soil ecosystem responses to land management practices, and the development of new technologies to assess these responses, also represent significant advances to the scientific community. These contributions have extended conceptual theory used in developing sustainable management strategies for these complex ecosystems and have practical implications for policy development regarding possible carbon credit and greenhouse gas-trading programs.

Jerry's scientific reputation is clearly illustrated by his numerous invitations to international and national meetings and his selection as a Fellow in 4 major professional societies: Soil Science Society of America, American Society of Agronomy, Society for Range Management, and Soil and Water Conservation Society.

Jerry's career epitomizes what the rest of us strive for: sustained excellence, impact, implementation of recommended strategies and practices by land managers, an illustrious publication record, and consummate respect among peers.

Thus, it is with great honor that we, hereby, present $\mathrm{Dr}$ Gerald (Jerry) E. Shuman with the 2006 W. R. Chapline Research Award.

The W. R. Chapline Stewardship Award was created in 1986 to provide recognition to members of SRM for exceptional accomplishments and contributions to the art and science of range management through specific rangeland entities.

The Deseret Land and Livestock Ranch located in northeastern Utah is widely recognized as one of the bestmanaged ranches in the United States. Established in 1891, for sheep grazing, the Deseret is a 200,000 acre, privately owned ranch, dedicated to the proper management of land, water, and animals. Owned and operated by the Farm 


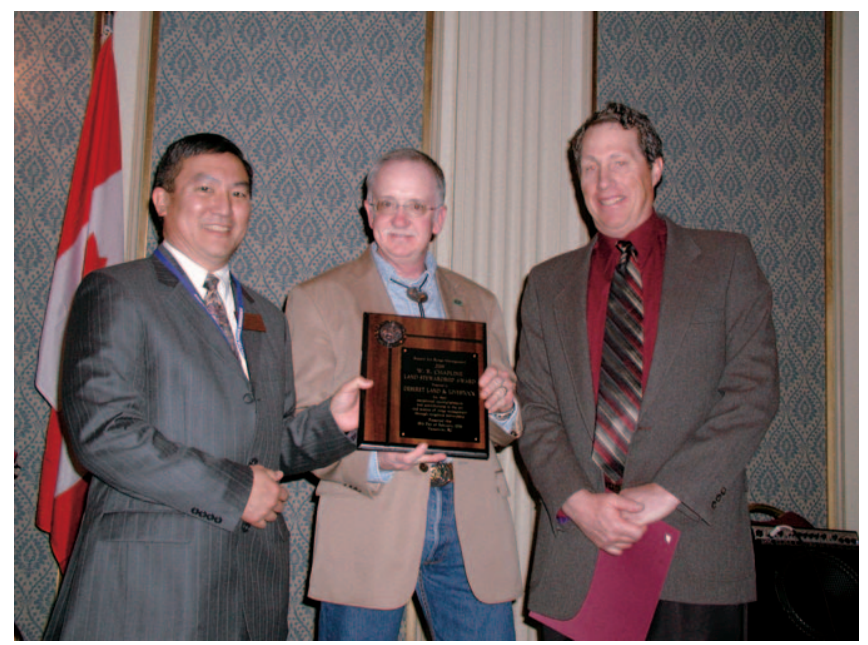

John Tanaka, Gregg Simonds, and Rick Danvir (not present: Bill Hopkin)

Management Company, a tax-paying entity of the Church of Jesus Christ of Latter-day Saints, the ranch mission is to "make a profit while maintaining or enhancing the resource." The 200,000 acres of rangelands on this property uniformly meet the criteria for being in a high state of ecosystem health. Approximately 5,000 mother cows, 3,000 yearlings cattle, and one of the healthiest mixes of wildlife in the region (including an estimated 3,500 mule deer, 2,300 elk, 175 moose, 700 antelope, 2,000 sage grouse, and 275 different species of birds) graze the ranch's rangelands.

This award recognizes the employees and volunteers that have contributed to the success of the Deseret Land and Livestock Ranch during the past 25 years-including those that have provided management and labor to the property and the LDS Church, which owns the ranch. This team has made major changes to the ranch that have improved its economic viability and ecological health. To achieve what they have on the ranch, those working the ranch have been innovators in land, livestock, and wildlife management, and the management techniques and ideas they have developed on the Deseret are being applied by other ranchers throughout the western United States. The ranch has been actively involved in outreach to inform other ranchers and the public about the opportunities for, and benefits of, improved rangeland management. The ranch workers have hosted numerous tours-including many SRM tours-to share their philosophies, experience, and knowledge with many diverse groups. They have been recognized by many organizations for the outstanding job they do in managing the land, water, and animal resources of the Deseret Land and Livestock Ranch.

The Society for Range Management is proud to join these other groups by presenting to the ranch the W. R. Chapline Stewardship Award - the highest award presented by the Society for those involved in resource management. Three individuals-all active SRM members-will accept the award on behalf of the ranch employees, volunteers, and owner. These individuals are Gregg Simonds, who managed the Deseret from 1981 to 1994; Rick Danvir, who joined the ranch as a wildlife biologist in 1983 and has been responsible for the wildlife management program on the ranch since 1990; and Bill Hopkin, who was responsible for livestock operations from 1983 to 1994 when he succeeded Gregg as manager.

\section{Outstanding Achievement Awards}

The Outstanding Achievement Awards are presented by the Society for Range Management to members and other qualified individuals and groups working in rangelands. The Outstanding Achievement Awards have been divided into 2 groups: Research/Academia and Stewardship (ranchers, agency professionals, and consultants).

\section{Research/Academia}

Dr Amitrajeet A. Batabyal grew up in the small railway town of Chittaranjan, West Bengal, India, before moving to the United States in 1983. He was educated in economics at Cornell, the University of Minnesota, and the University of California at Berkeley. He began to seriously research issues and problems in range management while at Utah State University.

While reviewing the relevant literature on the use and management of natural resources and rangelands, Dr Batabyal noticed that although there were many claims about whether the stocking rate or the length of time that animals grazed a particular rangeland was more important from a management perspective, there were absolutely no theoretical analyses of this important and much debated question-so he developed a novel stochastic model that clearly demonstrated the relative salience of stocking rate.

His 2002 Journal of Range Management article on the theoretical formation of the state-and-transition idea simply and nicely uses the theory of discrete-time Markov chains to show how the stochastic dynamics of a 4-condition-class rangeland can be modeled and understood. Although rangelands have often been conceptualized and managed from primarily an ecological perspective or an economic perspective, there is interest in jointly determined ecological-economic systems. His 2005 research showed that ecological and economic criteria are largely disjoint, except in unusual circumstances, and that optimizing one will not simultaneously result in the optimization of the other.

Dr Batabyal is a brilliant researcher and author, as exemplified by his book, Stochastic Modeling in Range Management: Selected Essays (Nova Science Publishers). He is internationally published and is a sought-after speaker. $\mathrm{He}$ also serves SRM as a book reviewer (20-plus published reviews in JRM/REM and Rangelands).

Dr Batabyal is one of the youngest holders of an endowed chair at the Rochester Institute of Technology (Arthur J. Gosnell Chair/Professor of Economics). He is most deserving of the Outstanding Achievement Award. 


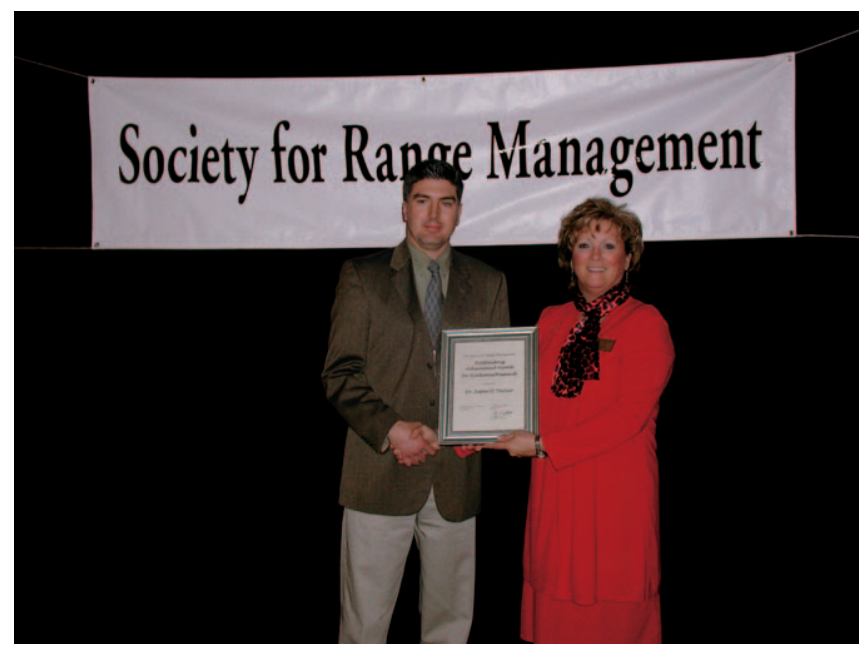

Justin Derner and Angela Williams

Dr Justin D. Derner has made outstanding contributions to the Society for Range Management both through his work with students and through his research. His work with students comes naturally because he was fully involved in the Range Club at the University of Nebraska. He served as the team coach for the Undergraduate Range Management Exam at both Oklahoma State University and Texas A\&M University Range Club. He continues to work with students at the University of Wyoming Range Club and assists with coaching and training of students even though he is located 50 miles from the University - he doesn't let 50 miles deter him from his interest or his love of working with students. He is currently serving as Chair of the Undergraduate Range Management Exam Committee and is a member of the Student Activities Committee at the International Society level. Justin is one of those special people who is an effective teacher and very well liked by the students because he relates well to them. Dr Derner has significantly influenced many students to continue their education and training in rangeland science.

Dr Derner has also developed an outstanding research program in rangeland ecology and the effect of climate change on rangeland ecosystems. Justin has published more than 35 refereed scientific journal articles, made more than 50 presentations, and been sought out to speak at more than 20 regional and national workshops or conferences. He has attended 16 annual meetings of the Society and made 17 presentations at those meetings. These statistics are quite extraordinary considering that he has been in his research career for only 6 years. Justin's research involves very timely and important rangeland issues: the effects of climate change on rangeland ecosystems, rangeland carbon sequestration, and evaluation of the "state and transition" model of plant community change. This theoretical approach to rangeland ecology is being adopted by land management agencies with limited or no research data to support or refute the model. His research includes areas of prime importance to future rangeland management and represents very challenging and difficult areas of research, but Justin doesn't let that discourage him-he loves the challenge and the natural resource-rangeland!

Dr Justin D. Derner is an extraordinary recipient for the Society for Range Management's Outstanding Achievement Award.

Dr Linda H. Hardesty, teacher, researcher, and extension specialist from Washington State University, is one of the truly capable and dedicated rangeland managers in the Society for Range Management. She has been active in her pursuits of rangeland improvement and managerial excellence throughout her entire 31-year professional career. She has made a tremendous difference wherever she has been, be it locally, regionally, nationally, or internationally. She has mentored many students, all of whom have gone on to productive and useful careers. She has successfully garnered grants and produced practical, useful research that has made a dramatic difference in the management and economic practicalities at each site and in every nation where she has worked. She is a wonderful undergraduate teacher whose student evaluations at the end of each term indicate that "she cared," "she taught me more than any other instructor at the University," and "she knows her stuff, has enthusiasm for it, and really knows how to sell it!"

Dr Hardesty's efforts within the professional Society for Range Management are strong and commendable. She works unselfishly for the betterment of rangelands and for the people associated with them. She has served on many SRM committees, has been President of the Pacific Northwest Section, served on the SRM Board of Directors, and has patiently and capably given depth and breadth to our organization and profession.

Dr Hardesty is a soft-spoken, gentle person who attempts to see the best in every situation and person. At the same time, she has strong goals and ethics, a sense of right and wrong, and a desire to make the world more livable because of her efforts. And she has done so! The world, its students, its landowners, her peers, and society are better because $\mathrm{Dr}$

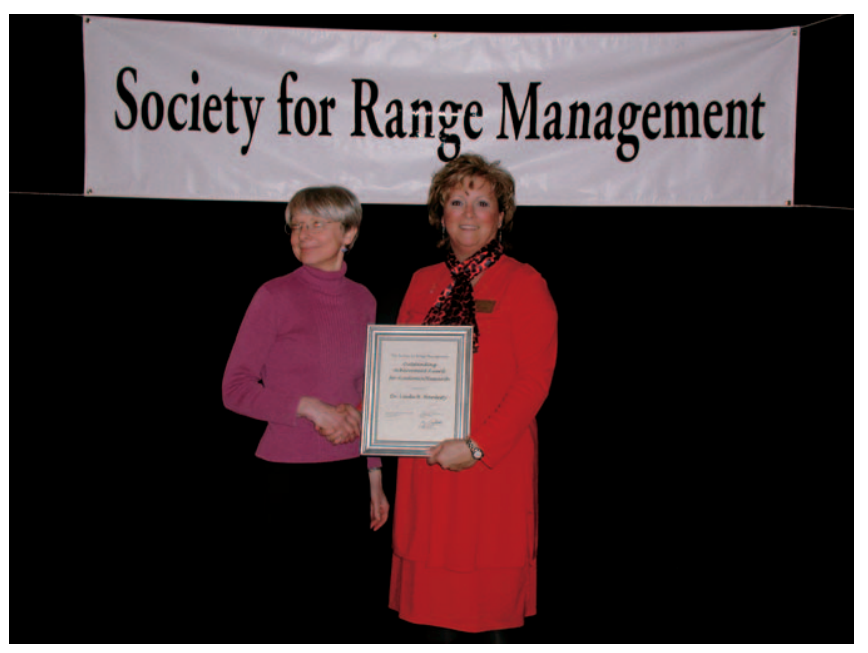

Linda Hardesty and Angela Williams 


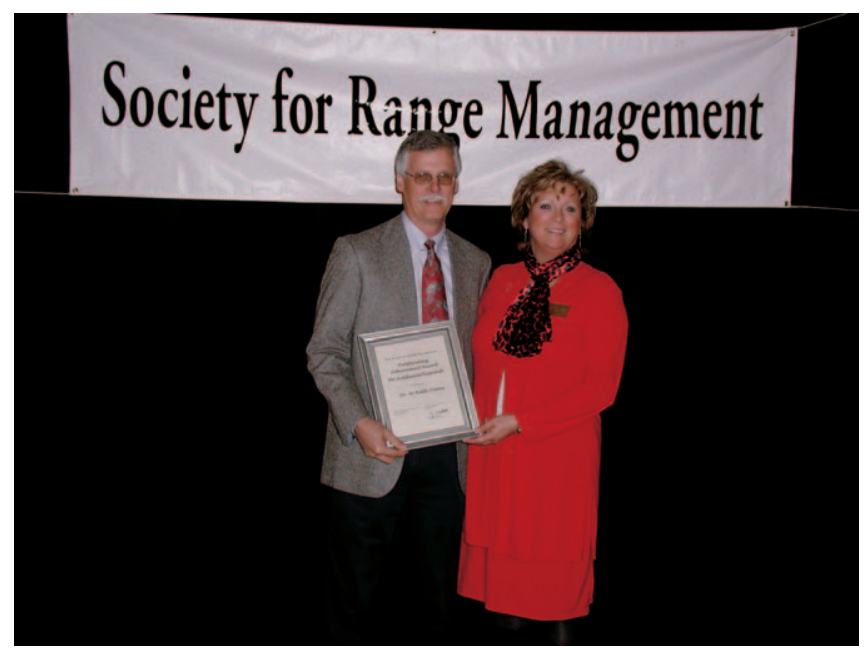

M. Keith Owens and Angela Williams

Hardesty has spent her considerable energy, time, and talent on the behalf of the rangelands of this planet!

Dr M. Keith Owens has a worldwide reputation for excellence in rangeland management research. During the past 15 years, he has been awarded $\$ 2,500,000$-plus for individual and joint research proposals to investigate ecological and managerial questions at multiple spatial scales. A central issue in Texas has been the availability and sustainability of water resources. Dr Owens has led efforts in understanding water use patterns in dominant trees and shrubs of the Edwards Plateau in Texas. This work has largely been on individual leaf, branch, and plant scales and has been incorporated into simple models for plant community water use. With collaborators, he has also been investigating water production from small watersheds and experimental rainfall simulator plots. He has worked with local and state entities to develop a network of experimental sites over a wide geographic range and to provide the data on a nightly basis through the Internet. Projects at a larger spatial scale have included foraging behavior of domestic livestock and wildlife within individual plant communities and fire behavior during summer fires in south Texas. Larger spatial-scale projects include foraging patterns of cattle and deer in large (2,500 acre) pastures and sampling protocol and foraging behavior of reindeer in the Bering Land Bridge National Preserve in Alaska. Ranchers and range professionals are both looking to Dr Owens for leadership in the management and understanding of rangelands.

A hallmark of Dr Owens' research is his ability to develop interdisciplinary teams of scientists to address specific problems facing Texas ranchers. Dr Owens has been active within Texas A\&M University's Texas Agricultural Experiment Station in Uvalde, Texas (the Uvalde Center), the Department of Rangeland Ecology and Management, and the College of Agriculture and Life Sciences. He has been an active member of the departmental tenure and promotion committee that evaluates all teaching, research and extension faculty with the Department of Rangeland Ecology and Management, and on the college Tenure and Promotions Committee. He has also participated in the Experiment Station Committee on Policy's Leadership Development course to enhance his capabilities in agricultural leadership. $\mathrm{He}$ is a member of a long-term research and management team at the Uvalde Center, which sets priorities for research in the context of a viable ranch enterprise. These accomplishments are the basis for recognition of Dr Keith Owens with the Society's Outstanding Achievement Award.

Dr Anthony (Tony) J. Svejcar, as scientist and Research Leader for the USDA-ARS in Burns, Oregon, has exceptional and sustained research accomplishments that have helped shape the science and management of rangeland resources. Tony is recognized nationally because he has dedicated his career to understanding and improving our rangeland resources, has worked tirelessly to bridge the gap between range science and range management, and has fostered the development of range science by building the largest rangeland research program in the Great Basin and surrounding ecosystems.

Dr Svejcar pioneered the use of stable isotope ${ }^{13} \mathrm{C}$ for carbon cycle research (in both plant and animal), and he initiated the ARS $\mathrm{CO}_{2}$ Flux Network, an effort to identify the influence of US rangelands on the global carbon cycle. Tony and his coworkers have provided substantial knowledge about the ecology and management of western juniper to land managers throughout the western United States. He has helped frame and define our knowledge on the ecology of riparian vegetation and provided guidance on managing the impact of livestock on riparian ecosystems. Dr Svejcar has studied the effects of precipitation timing on intact native sagebrush plant communities, and he has developed ecologically based models and principles useful in protecting these systems from invasion by weeds.

Perhaps Dr Svejcar's greatest contribution to rangelands has been to direct the Eastern Oregon Agricultural

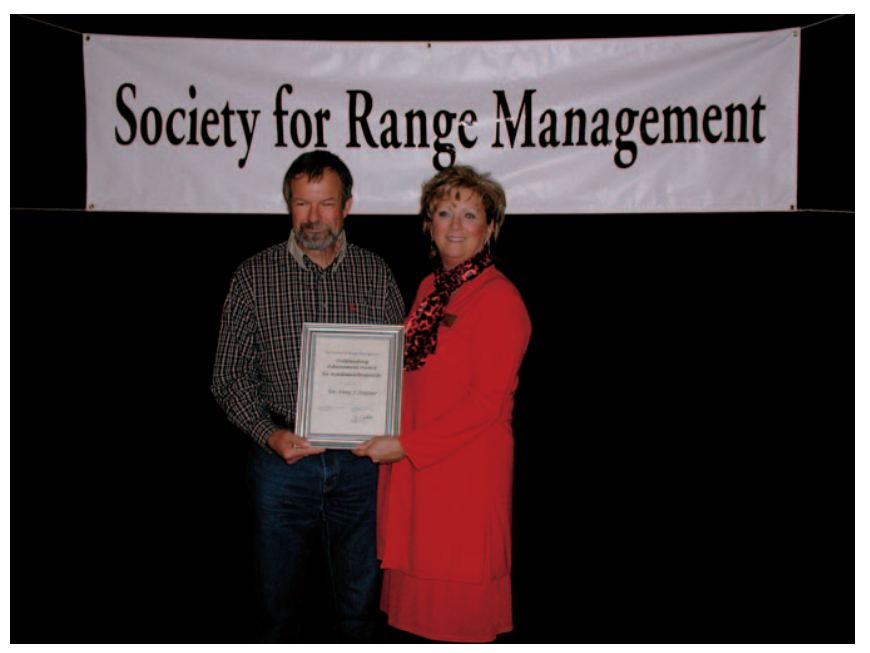

Tony Svejcar and Angela Williams 


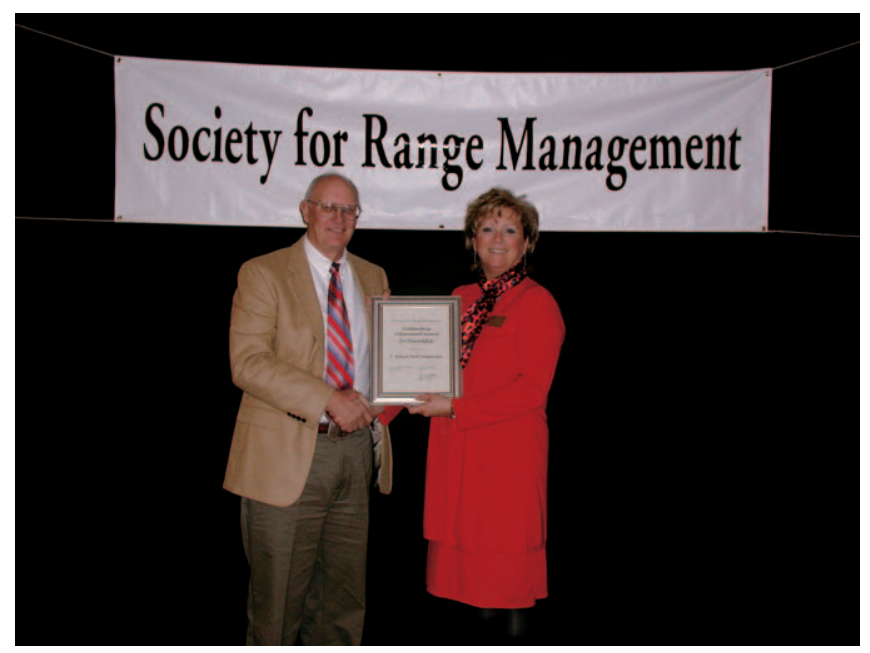

Bob Alexander and Angela Williams

Experiment Station into a high-quality, energetic, and productive research program. His excellent research skills are only surpassed by his ability to motivate, mentor, and lead other scientists to make their own substantial contributions to understanding and managing our treasured rangelands.

\section{Stewardship}

Robert (Bob) Alexander has, for 37 years, practiced and promoted the art and science of rangeland management. From the field offices of the Bureau of Land Management (BLM), to the desert rangelands of the Middle East, to the Beltway environment of Washington, DC, and finally, to the BLM state office in New Mexico, Bob has constantly worked for the conservation of rangelands.

Bob has numerous qualities that have served him and his profession well. There are 2 that are of particular significance in support of this award nomination.

First, he has never ceased to learn, adapt, and adopt. Even after more than 30 years of experiences, he still looks to understand new information, to develop new ideas, and to influence public land policy. For example, he was an important collaborator and coauthor in the 2003 publication on the development of state-and-transition models for rangelands, published in the Journal of Range Management. He was 1 of 2 people who started that program, which resulted in the $J R M$ publication and which continues today.

Second, Bob works constantly to bring different groups, agendas, and perspectives together into collaborative efforts. Whether as a Section President or as a Range Conservationist, he has worked to get people and groups to communicate and to move forward. His work with the rangelands standards and guidelines is one example.

Bob is a dedicated, hard-working, effective, and creative range manager. He deserves this award from the Society for Range Management.

Ted and Olive Perrin own and operate the 12,775-acre

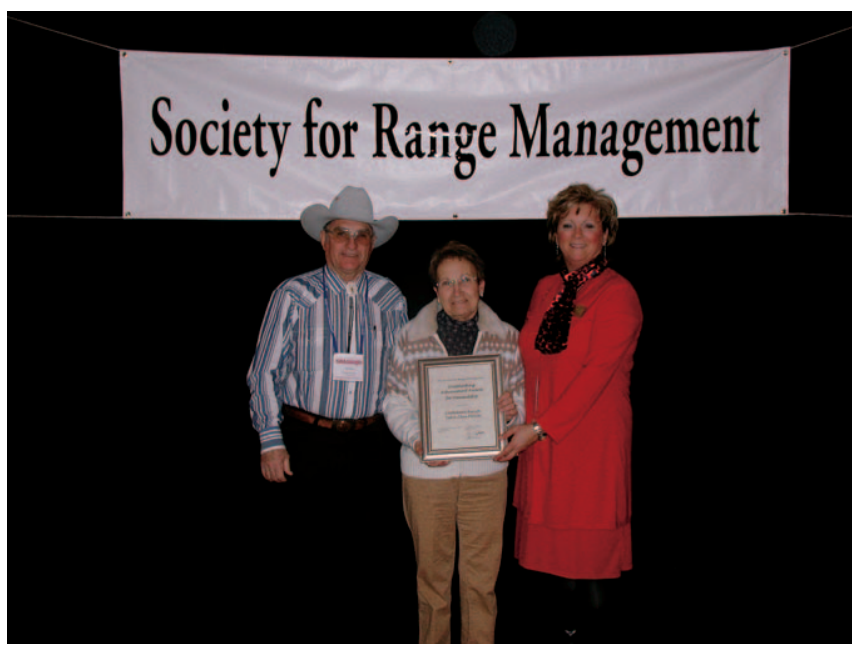

Ted and Olive Perrin and Angela Williams

Castleland Ranch in the Northern Mixed Prairie near Beechy, Saskatchewan, Canada. Castleland Ranch is a recognized leader in range management in the Canadian ranching industry. Forward-thinking and conservative range management on Castleland Ranch ensures sustainable grazing resources through extremes in climatic conditions over the short and long term. Many of the long-standing management approaches of Castleland Ranch are new technology for many producers.

Drought is a fact of life and an overriding consideration in the management of Castleland Ranch. The Perrins recognize the value of planned grazing systems that include conservative stocking rates, resting of plants during the growing season, once-over grazing, balanced forage availability and livestock numbers, and drought-proofing. Maintaining relatively stable animal numbers from year to year has been a major benefit derived from drought-proofing the range on Castleland Ranch.

Environmental stewardship on Castleland Ranch has been recognized by the Perrins' receiving The Saskatchewan Environmental Stewardship Award, The Canadian Environmental Stewardship Award, and the Prince Philip Heritage Award. The Perrins have cooperated with several conservation organizations, and they have been involved in rangeland studies conducted by universities.

Ted and Olive Perrin are extensively involved in the ranching industry and community activities. Ted was a member of a contingent of ranchers and rangeland specialists belonging to the Society for Range Management that toured rangelands of Inner Mongolia in 1990, sharing technology and range management practices. Ted is also a mentor for local producers who want to improve their range management.

Ted and Olive Perrin realize that ranching and range management are all about conserving natural resources for future generations. The Perrins strive to maintain a high quality of life and a lifestyle that is as rich, diverse, and generous as the 
landscape in which Castleland Ranch is located. Applying principles of range management that allow sustainable use of rangeland resources has been rewarding, as evidenced by humble and happy landowners and healthy rangelands.

Ted and Olive Perrin of Castleland Ranch are deserving recipients of the 2006 Outstanding Achievement Award.

Jeffery L. Printz has been a gracious contributor to rangeland management technology throughout his career. He has worked in various positions throughout the state of North Dakota. His current position with USDA-Natural Resources Conservation Service (NRCS) as the State Rangeland Conservationist has enabled him to be involved with the development and implementation of technical guidelines and standards, technical presentations and publications, and education of peers, agency personnel, and producers in relation to rangeland management. Jeff has participated in the collection and interpretation of rangelandrelated data to be used in statewide references. He has helped complete investigation studies and to develop ecological sites and forage suitability groups to determine characteristics and classification for use in planning and application of rangeland resource management systems. Currently, he serves on the Ecological Site Description task force. As a task force member, he has helped develop the regional strategy plan for new ecological site descriptions and forage suitability indexes for each state in the region. Jeff has worked with individual producers, producer groups, and state and federal agencies to help correlate these standards and to promote a uniform understanding of rangeland management objectives.

Jeff also has statewide responsibility in North Dakota for NRCS' Forage Quality and Animal Well-being project and the associated Nutritional Balance Analyzer program, which is a nationwide project, involving a cooperative agreement between NRCS and the Grazingland Animal Nutrition Lab at Texas A\&M University. NRCS field staff work with ranchers in determining the diet quality their grazing animals are obtaining from the forage available to them. Jeff provides overall leadership for this program and trains NRCS employees in the collection method, operation of the computer software, interpretation of the results, and overall quality control.

Jeff has also been very dedicated to the Society for Range Management. He has served as an inspirational force for both new and old members alike. His cheery attitude creates a positive and inviting environment for members to become involved in SRM activities. Jeff has served on various committees over the years and has even served as a North Dakota Chapter President and a Northern Great Plains Section (NGPS) President. He has also been involved with youth activities, such as the North Dakota Regional Range Judging Contest and North Dakota Youth Range Camp.

Since the National Research Council issued its report on Rangeland Health in 1994 and the Society for Range Management issued its report on Unity in Concepts and

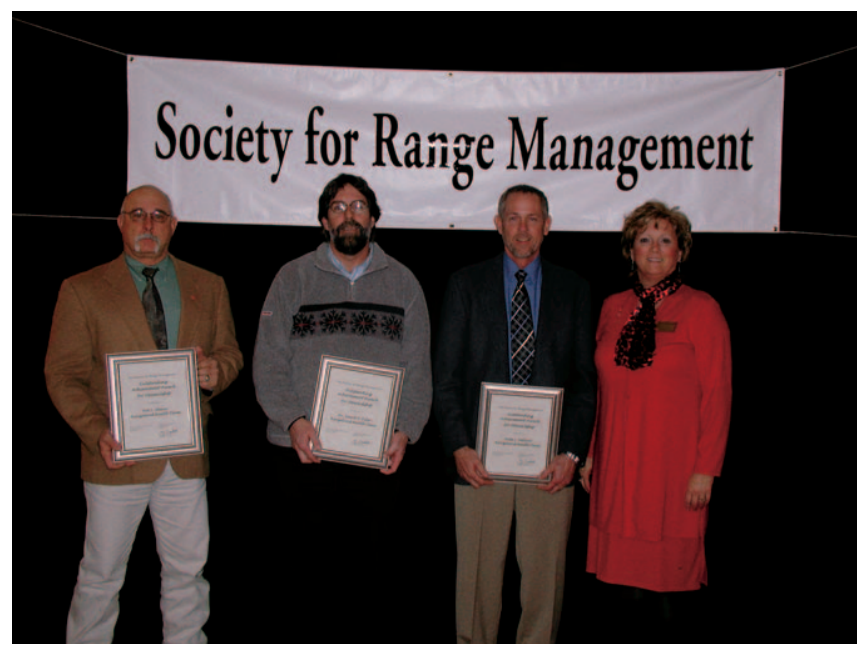

Pat Shaver, David Pyke, Mike Pellant, and Angela Williams (not present: Jeff Herrick)

Terminology in 1995, Jeffrey E. Herrick, ARS; Mike L. Pellant, BLM; David A. Pyke, US Geological Survey (USGS); and Pat L. Shaver, NRCS, have worked to determine how the ideas included in these reports can be incorporated into rangeland management. This interagency team has conducted field work to better develop the ideas introduced in the original publications, authored peerreviewed and technical publications summarizing what they learned through these field studies, and conducted many workshops to demonstrate the utility of the rangeland health concept.

The Rangeland Health Team has more fully developed the idea introduced in Rangeland Health of how multiple attributes could be used for assessment of the soil, watershed, and biotic conditions of a site. The team brought into the rangeland health assessment process important components of SRM's Unity in Concepts and Terminology report, particularly on the importance of ecological site descriptions. The team has consistently emphasized that a rangeland health assessment is a point-in-time evaluation that can help a resource manager identify areas with problems that need to be addressed-in other words, a way to prioritize work. The team emphasizes that what has caused a problem cannot be determined from a rangeland health assessment nor can rangeland health be used to monitor trends.

In summary, the Rangeland Health Team has taken basic concepts - developed by the National Research Council, the Society for Range Management, and many rangeland scientists and managers - and has advanced these concepts to a new level, has taken the ideas to the field for numerous tests, and has provided the rangeland management community with new tools to evaluate rangelands.

The Society for Range Management is pleased to recognize Jeff Herrick, Mike Pellant, Dave Pyke, and Pat Shaver for their important contributions to our profession with the Outstanding Achievement Award. 


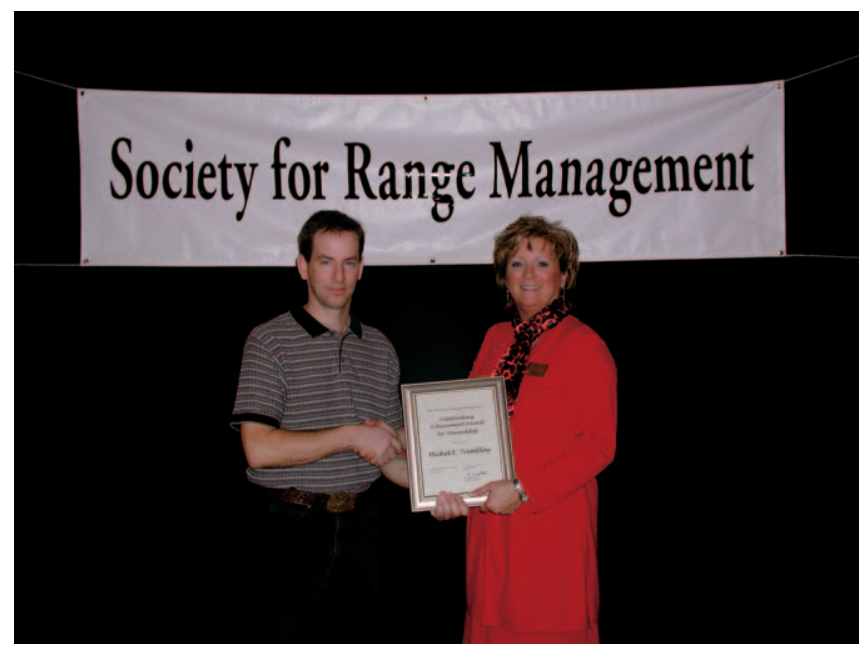

Michel Tremblay and Angela Williams

Michel E. Tremblay is presented the Outstanding Achievement Award for his continued service and dedication to improving the management and conservation of rangeland resources and the rangeland management profession. He has been an active member of the Northern Great Plains Section for more than 15 years, taking on a wide variety of executive roles.

As Provincial Forage Specialist for Saskatchewan, Canada, since 1992, Michel has played a key role in delivering sound technical advice to other government departments, the forage industry, and forage producers. Growing up in an agriculture environment, Michel has complimented that knowledge with a BS in Agriculture and an MS in Range Management. Michel's agriculture background, combined with his knowledge of Saskatchewan's agriculture, livestock, and forage industries, has led him to become a key range management professional in Saskatchewan that other agencies and producers count on for extension information. He has authored numerous fact sheets and helped revise range related documents - these publications are considered keystone information on forages and range management for Saskatchewan. Michel has continued to follow developments in the native forages industry and promote them where feasible. He also has played a key role in promoting the wise use of native rangelands to wide audiences in the province.

Michel has been instrumental in his role as Provincial Forage Specialist with Saskatchewan Agriculture and Food in bringing together and working with partner agencies to develop programs and extension materials that benefit Saskatchewan's livestock and forage industry. He has been influential in ensuring the long-term viability of the Saskatchewan Forage Council through fundraising, carrying out executive roles, and providing basic networking with industry. At a national level, he has also played a leadership role in developing Saskatchewan's forage industry. He is committed to continually developing professionally by reading new information in range management journals and publications and by attending workshops and conferences throughout Canada and the United States.

Michel's long-term service and passion in advancing the art and science of rangeland management make him a most worthy recipient for the SRM 2006 Outstanding Achievement Award.

\section{Sustained Lifetime-Achievement Award}

The Sustained Lifetime-Achievement Award is presented by the Society for Range Management to members for long-term contributions to the art and science of range management and to the Society for Range Management.

George S. Cook completed his BS in Range Management at Utah State University (USU). He then began a long and distinguished career with USDA-NRCS, where he worked as a Soil Conservationist, Range Conservationist, and District Conservationist. George has received many awards in the past, such as the Utah Soil Conservation Commission "Graham S. Quate" Award, the Utah Section SRM Range Manager of the Year Award-1995, the SRM Fellow Award-2000, and the USU Alumni Association Lifetime Achievement Award-2002. He has been very active in the Society for Range Management at the national and section levels, including service as Utah Section President in 1991 and SRM Information and Education Committee (I\&E) member in 1995-1996. He is a person who faithfully attends all the section and national SRM meetings, even now that he is retired.

George's most distinguished services to the Utah Section have been to host Dutch oven and steak cookouts around the state to collect money for the section's scholarship fund. This has earned the section approximately $\$ 50,000$, which has been invested into the scholarship fund to promote the range management profession to students. Also, for 23 years, George has annually given freely of his time to teach and help USU Extension at the Utah Natural Resources Field

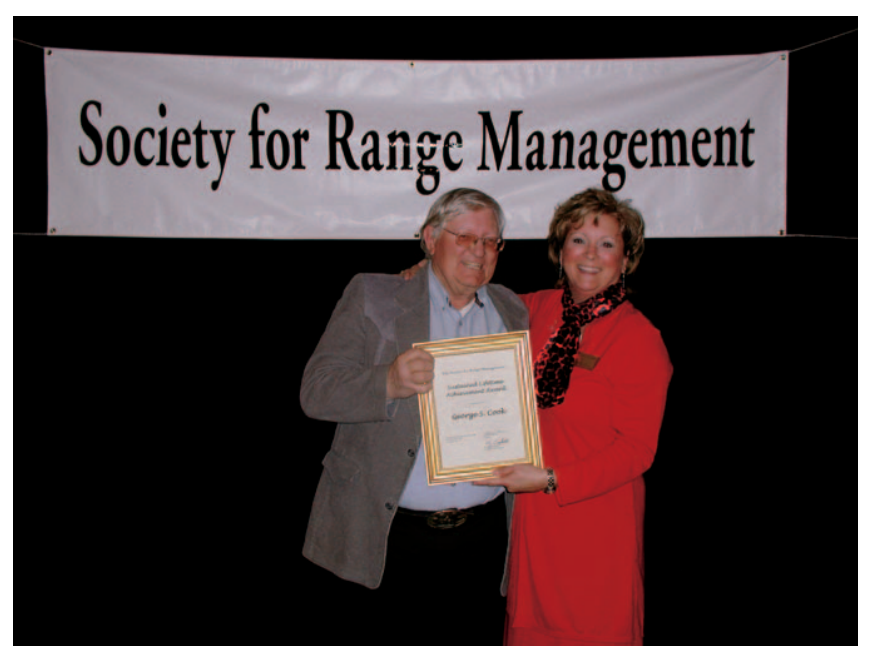

George Cook and Angela Williams 
School (UNRFS), which hosts 8-25 high-school students, who learn about range and natural resource management. George's humble, patient, and gentle teaching style has positively affected approximately 300 students.

While at NRCS, George wrote many of the Range Site Descriptions that are now or have been developed into Ecological Site Descriptions. He brings a passion to the job, not only for the science but also for the information that flows out of that science. His close work with the western states Plant Materials Centers has provided experimental and new plant varieties for rehabilitation and planting trials on many harsh and inhospitable sites, such as coal mine tailings or other disturbed sites. George has helped many of the new NRCS personnel become familiar with ecological sites and with the land they are responsible for managing. He is an authority in conservation of the land and in plant identification and is a champion for conservation transfer to those who follow in the profession of range management.

George and his wife, Sarah, have 2 children and 6 grandchildren.

Paul T. Tueller is recognized internationally as a leader in remote-sensing applications on rangelands. He joined the Society for Range Management in 1956. Looking down the long trek into history, he has seen the vagaries of weather, personnel changes, issues, controversies, priorities, legislation, and land uses. He has sweated on the pages of 1950s field notebooks and worked with some of the highest and most current digital technologies that the National Aeronautics and Space Administration (NASA) has at its disposal. He has worked in both the Mojave Desert and the Great Basin sagebrush and sagebrush steppe systems of Nevada.

He has seen it all from the ground, from the air, and from space, an accomplishment no one else can claim. Paul bleeds rangelands. The profession is his passion, and he has dedicated himself to it for nearly 50 years. He is best known for

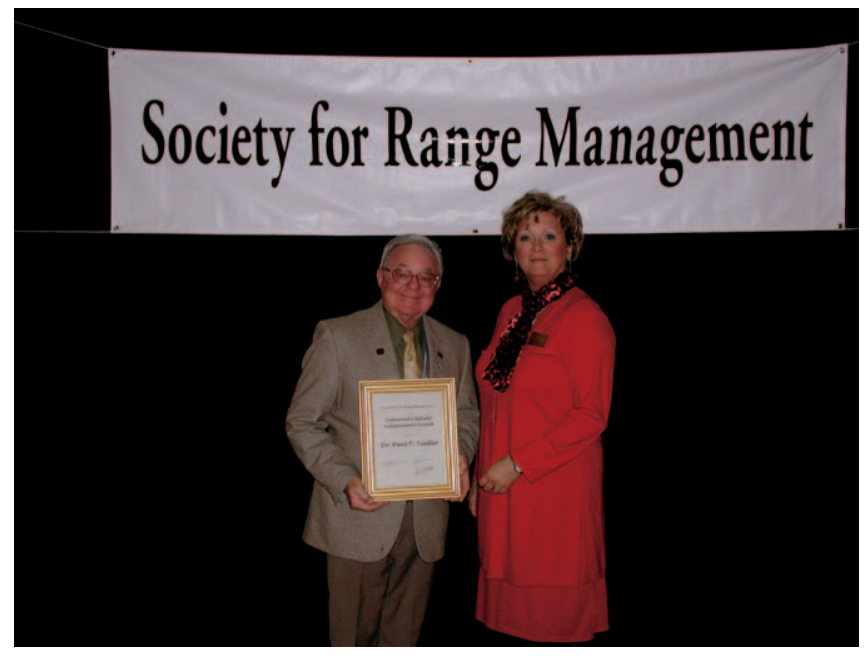

Paul Tueller and Angela Williams his precedent-setting research in remote sensing. Paul is one of the pioneers in this area of science and has not only assisted in development of the technology itself but also been a champion and innovator in applying remote sensing to rangeland management.

In our profession, the highest tribute one can give is to acknowledge them as a Rangeman. Paul Tueller is a Rangeman. He is a credit to our profession - an ethical, moral, enthusiastic, positive, and beloved family man. His former graduate students are located all over the country; many of them have served and are serving as district managers and forest supervisors in federal land management agencies. We cannot begin to measure the effect their relationship with Paul and his research has had on our rangelands. The body of research that Paul has accumulated throughout his nearly 50 -year career is impressive. He is a research icon in our profession and deserves formal recognition as such.

\section{Outstanding Young Range Professional}

The Outstanding Young Range Professional Award is presented by the Society to an individual member who has demonstrated extraordinary potential and promise as a range management professional. This award is presented as an encouragement for outstanding performance by young men and women entering the profession of range management.

Jason C. Hohlt is a Rangeland Management Specialist for the Natural Resources Conservation Service in Alice, Texas. Since coming to work for the NRCS, Jason has worked in Victoria, Jim Wells, Live Oak, Duval, Brooks, McMullen, and Kleberg counties.

Some of Jason's accomplishments include a BS degree in Rangeland Ecology and Management from Texas A\&M University (TAMU) and an MS in Animal Science from Texas Tech University. He holds a basic firefighter certificate from the BLM and is a Certified Wetland Delineator. $\mathrm{He}$ has been Treasurer of the TAMU Range Club and President of the TAMU Soil and Water Conservation Society. Jason is

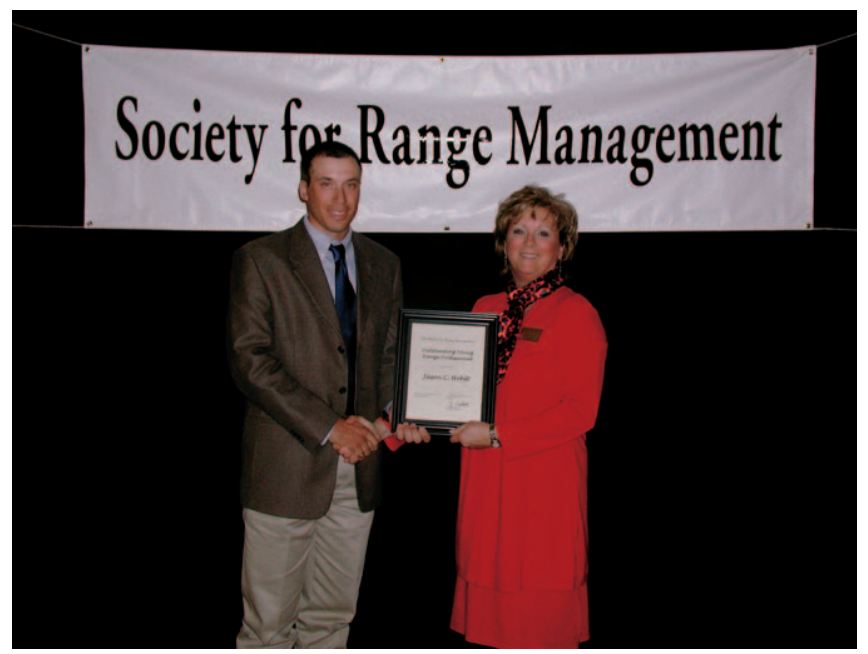

Jason Hohlt and Angela Williams 
the recipient of the National Soil and Water Conservation Society Achievement Scholarship, Range Club Outstanding Participation Scholarship, and a Certificate of Merit from NRCS for Outstanding Leadership on the Natural Resources Inventory Team.

Jason is highly intelligent, learns quickly, is highly motivated, and practices a high moral code with absolute integrity. It is truly a rarity to find a young employee as enthusiastic, positive, inquisitive, and with as much integrity and work ethic as Jason. Jason has a heart for rangelands and resource management, and his enthusiasm for these is contagious to all who come in contact with him. Jason is a self-starter, and no job, regardless of its complexity, daunts him.

Jason is a natural leader. His ability and willingness to take the leadership role is a quality few young employees possess. He has a special ability to communicate effectively with others while promoting sound resource management and will stand for what is technically sound even though it may not be the most popular choice.

Jason's love for his chosen profession and the rangeland resource is evident to all who work with him, and it is an honor to recognize Jason Hohlt as the 2006 recipient of the SRM Outstanding Young Range Professional Award.

Lee A. Knox is one of SRM's shining stars. He has an enthusiasm that is infectious. His leadership skills have been recognized by the Texas Section and by his employer, the Natural Resources Conservation Service. Lee has been active on numerous Texas Section committees and is currently serving as Chair of the Youth Activities Committee. This committee is responsible for the annual Youth Range Workshop. He was selected to be a watershed manager for the NRCS Conservation Security Program (CSP). In this role, he had a positive impact on the other CSP watersheds in the San Angelo zone. Lee came to NRCS from Texas Cooperative Extension (TCE). The TCE honored him in 2002 with its District 10 Outstanding Young Agent Award.

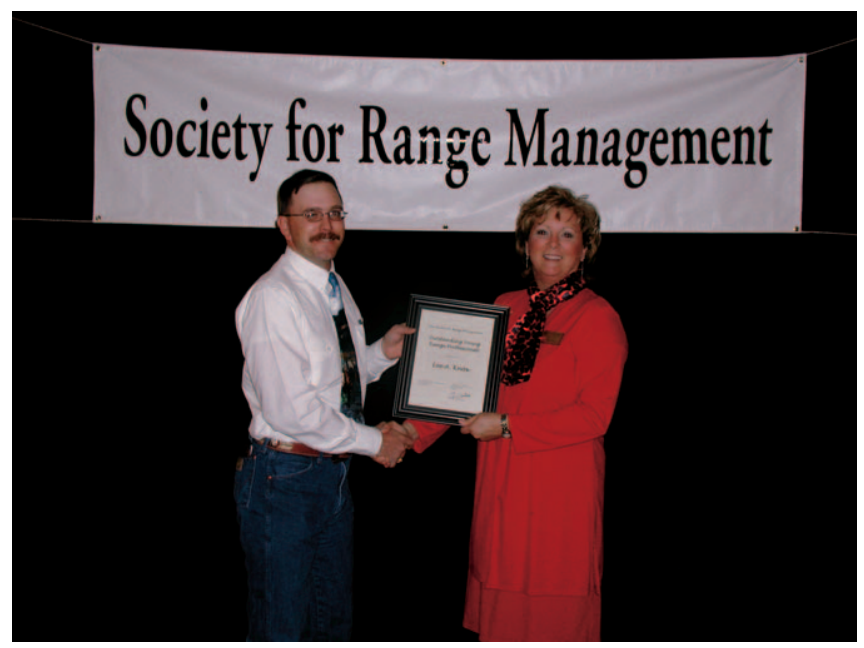

Lee Knox and Angela Williams
Lee earned his BS in Rangeland Management from Texas A\&M University in 1996. That same year, he was selected by the professors of the department to receive the Leadership Award, their most prestigious student award. He earned his Master's degree in range management from New Mexico State University. At the 1998 Annual Meetings in Guadalajara, Mexico, Lee won the Graduate Student Paper Contest, while presenting the results of his MS thesis.

Lee's enthusiasm for, and dedication to, rangeland management and SRM makes him a shining example for other young professionals. He will be a leader at the section and society level for many years. It's this level of commitment and dedication that make him deserve to be recognized as one of the 2006 Outstanding Young Range Professionals.

Melissa R. Teague is an exemplary model of a Rangeland Management Specialist, which stems from a well-rounded knowledge base and an undeniable passion for rangelands. Melissa has been a Rangeland Management Specialist for the NRCS for 8 years in various locations in Texas and Oklahoma. She has been an area Range Specialist in southwest Oklahoma for 4 years, where she is the "go to" person for range-related topics. She has provided excellent leadership in an area that previously lacked support for range activities. Melissa has made a difference!

Melissa received her BS in Rangeland Ecology and Management at Texas A\&M University and her MS in Agribusiness and Economics at West Texas A\&M University. Her SRM activities include the Plant ID team and the Undergraduate Range Management Exam (URME) team at TAMU, the Student Activities Committee for 7 years, CoChair of the URME exam for 6 years, Coordinator for Tapping the Top Mixer, Secretary Treasurer for the Oklahoma Section in 2003-2004, and first vice president of the Oklahoma Section in 2004-2005, and she is currently the President of the Oklahoma Section. Since 2001, Melissa has been a coordinator and instructor for the Black Mesa Ecological Academy, a range and wildlife camp that brings together high-school students from Oklahoma, Texas, Kansas, New Mexico, and Colorado. In 2004, she was selected as the chair for this Academy, where the top student is selected to attend the National SRM meeting to compete in the High School Youth Forum. Melissa is also an invaluable member of a team that assists in the set up and instruction of the National Range Judging Contest held in Oklahoma City every year.

Melissa's tireless efforts to support rangeland management and sustainability and the endless amount of time spent in educating the range managers of tomorrow make her unquestionably deserving of this award.

\section{Range Science Education Council Outstanding Undergraduate Teacher Award}

The Outstanding Undergraduate Teaching Award is presented annually to the individual who makes the greatest contribution to undergraduate education in the broad discipline of range science. 


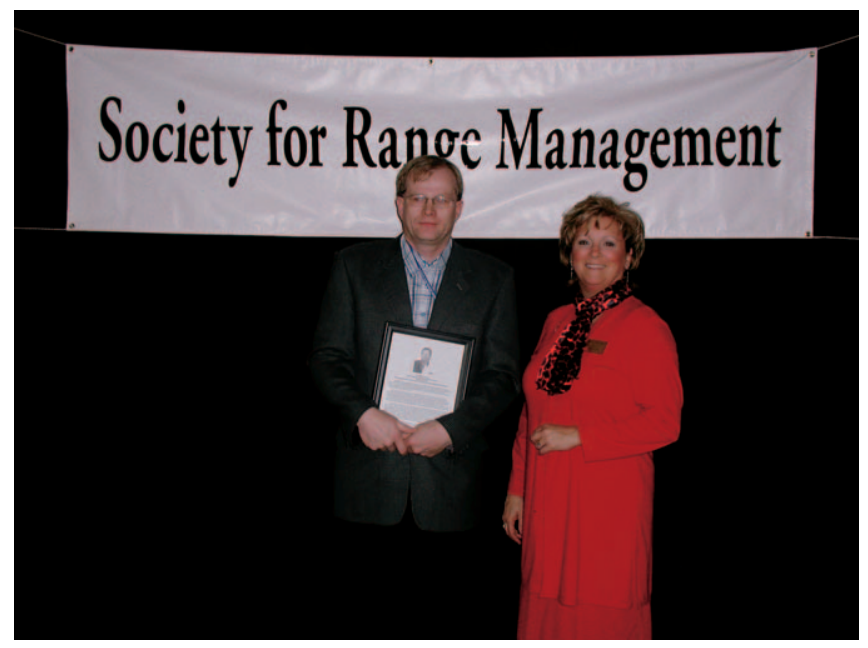

Barry Irving and Angela Williams

The award is presented jointly by the Range Science Education Council and the Society for Range Management.

The Range Science Education Council and the Society for Range Management are happy to present the 2006 Outstanding Undergraduate Teaching Award to Dr Barry Irving from the University of Alberta.

Dr Irving is well known among his colleagues as one of the most successful coaches of students in the Plant and URME contests. Under his direction, more than 70 individuals and teams have received awards in international competition. Students and fellow instructors at the University of Alberta recognize and admire Dr Irving for the hundreds of hours required each year to coach teams and advise the range club. Barry also works to make sure his students get summer work experiences and helps them find careers upon graduation. Students state that Barry is always trying to find ways to give students a great education, and he gives generously of his time beyond the classroom.

In his teaching efforts, Dr Irving is always trying to challenge students to achieve their highest personal best. Barry employs innovative and effective classroom experiences and teaching tools that coax students to rise to excellence. He has created interactive computer modules that quiz students on plant identification and classification. Barry is also known for making education fun and for engaging students by turning tests and assignments into games and team activities. For example, Dr Irving created "Plantionary," a game adapted from the Pictionary board game, where students guess families, genera, and species based on a partner's simple plant drawings. Students commonly note that Dr Irving pushes them to do their best work. Barry guides them beyond "book learning" and helps them achieve critical-thinking skills and confidence in their knowledge.

Dr Barry Irving excels in the classroom and beyond to help students understand rangelands and to achieve their career goals; therefore, he is recognized with the Outstanding Undergraduate Teaching Award for 2006.

\section{First Annual SRM International Travel Fellowship 2006}

The SRM International Travel Fellowship, presented for the first time in 2006, is awarded to a rangeland scientist or manager from a developing country. The purpose of this fellowship, which includes a \$1,000 travel stipend, is to foster international exchange about advances in rangeland ecology and management and to promote participation in SRM by rangeland scientists and managers from developing countries. The fellowship is competitive and is awarded on the basis of scientific merit and applied significance of research, financial need, professional development objectives, and clarity of expression in English.

The 2006 winner of the International Travel Fellowship is Rebeca Ideth Hernández-Paz, an MS student in Environmental Systems at the Instituto Superior de Estudios Tecnológicos de Monterrey in Monterrey, Mexico, for her paper titled "Organochlorine compounds in water and sediments of three tributaries of the Rio Bravo in Coahuila, Mexico." 